\title{
MENINGKATKAN KEMAMPUAN BERPIKIR KRITIS DAN PENGEMBANGAN KARAKTER MELALUI THINK PAIR SQUARE SHARE (TPSS) DALAM LESSON STUDY
}

\author{
Muhfahroyin \\ Pendidikan Biologi FKIP Universitas Muhammadiyah Metro \\ E-mail: muhfahroyin@yahoo.com
}

\begin{abstract}
The constructivist learning emphasizes that in learning a student constructs his knowledge with new knowledge which is obtained. The ability to construct knowledge relates to the ability of critical thinking, activity, and character. Therefore, constructivist learning as a device for the student to develop critical thinking activity, and character. The purposes of this research are to know the contribution of TPSS strategy toward the critical thinking, activity, character building. This research was implemented in the even semester academic year 2009/2010 in Biology Education Study Program FKIP UM Metro. Based on the research, the conclusion can be formulated that there was a contribution of TPSS strategy towards the learning activity, critical thinking, character building. The researcher suggests that teachers need to implement TPSS in biology learning, especially in Biology Education Study Program FKIP UM Metro.
\end{abstract}

Kata Kunci: TPSS, Berpikir Kritis, Pengembangan Karakter.

Amanat Undang-undang Nomor 20 Tahun 2003 tentang Sistem Pendidikan Nasional bahwa tujuan pendidikan nasional, yaitu mengembangkan potensi peserta didik agar menjadi manusia yang beriman dan bertakwa kepada Tuhan Yang Maha Esa, berakhlak mulia, sehat, berilmu, cakap, kreatif, mandiri, dan menjadi warga negara yang demokratis dan bertanggung jawab (Depdiknas, 2003). Tujuan pendidikan ini merepresentasi filosofi konstruktivisme yang menekankan pendidikan pada pemberdayaan peserta didik dan berpusat pada siswa (student centered). Pendidikan berbasis kompetensi yang berpusat pada siswa dinilai lebih dapat memberikan harapan pada generasi yang akan datang dibanding pendidikan yang berorientasi pada materi, karena melalui pendidikan berbasis kompetensi, lulusan akan memiliki pengetahuan, sikap, dan keterampilan yang lebih baik dibanding hanya menguasai materi saja (Depdiknas, 2005). Pembelajaran sebagai salah satu aspek pendidikan harus diselenggarakan dengan memberdayakan potensi yang dimiliki siswa, baik siswa yang memiliki kemampuan akademik tinggi maupun siswa yang memiliki kemampuan akademik rendah (Muhfahroyin, 2009a; 2009b).

Siswa sebagai individu yang unik dan berbeda antara siswa yang satu dengan yang lain dalam kelas, dapat dilihat dari kemampuan akademiknya. Perbedaan kemampuan akademik ini sangat penting diperhatikan dalam pembelajaran (Sidi, 2001; Winkel, 2004). Senada dengan hal tersebut, Richards (2002) menyatakan bahwa berdasarkan kemampuan akademik, maka ada tiga kelompok siswa, yaitu siswa berkemampuan akademik tinggi, siswa berkemampuan akademik sedang, dan siswa berkemampuan akademik rendah. Corebima (2006, 2007a, dan 2007b) menyatakan bahwa kesenjangan antara siswa berkemampuan atas dan bawah harus diperhatikan oleh pendidik dalam pembelajaran, diharapkan kesenjangan tersebut semakin diperkecil, baik dalam proses maupun hasil akhir pembelajaran melalui strategi yang memberdayakan potensi siswa berkemampuan berbeda ini. Pemberdayaan potensi siswa yang sangat penting adalah memberdayakan kemampuan berpikir kritis, aktivitas, dan 
pengembangan karakter dalam mengaktifkan dan mengembangkan pembelajaran maupun di luar kemampuan berpikir kritis pada siswa. pembelajaran.

Menurut Ennis dalam Splitter (1992) serta Fogarty dan McTighe (1993) berpikir kritis merupakan cara berpikir reflektif yang masuk akal atau berdasarkan nalar untuk menentukan apa yang akan dikerjakan dan diyakini. Berpikir menggunakan proses secara simbolik yang menyatakan objek-objek nyata, kejadian-kejadian dan penggunaan pernyataan simbolik untuk menemukan prinsip-prinsip mendasar suatu objek dan kejadian (Arends, 2004). Di dalam proses berpikir berlangsung kejadian menganalisis, mengkritik, dan mencapai kesimpulan berdasar pada inferensi atau pertimbangan yang seksama (Ibrahim dan Nur, 2000). Disampaikan oleh Diestler (1994) bahwa dengan berpikir kritis, orang menjadi memahami argumentasi perbedaan berdasarkan perbedaan nilai, memahami adanya inferensi dan mampu menginterpretasi, mampu mengenali kesalahan, mampu menggunakan bahasa dalam berargumen, menyadari dan mengendalikan egosentris dan emosi, dan responsif terhadap pandangan yang berbeda (Costa dan Presseisen, 1985). Berpikir kritis adalah proses yang melibatkan operasi mental seperti induksi, deduksi, klasifikasi, dan penalaran (Muhfahroyin, 2009b).

Berpikir kritis merupakan proses kognitif dan aktivitas mental untuk memperoleh pengetahuan. Liliasari (2000) dan Krulik dan Rudnick (1999) menyatakan bahwa kemampuan berpikir kritis merupakan aktivitas berpikir tingkat tinggi. Berpikir kritis ini mengaktifkan kemampuan melakukan analisis dan evaluasi bukti, identifikasi pertanyaan, kesimpulan logis, memahami implikasi argumen (Friedrichsen, 2001; Muhfahroyin, 2009a). Lebih lanjut McMurarry et al (1991) menyampaikan bahwa berpikir kritis merupakan kegiatan yang sangat penting untuk dikembangkan di sekolah, guru diharapkan mampu merealisasikan pembelajaran yang Perencanaan pembelajaran IPA oleh guru untuk pengembangan kemampuan berpikir kritis siswa adalah keharusan. Hal ini didukung oleh penyataan Friedrichsen (2001) dan King (1994) bahwa kemampuan berpikir kritis seyogyanya dikembangkan sejak usia dini. Dinyatakan oleh Presseisen (1985) bahwa agar siswa memiliki keterampilan intelektual tingkat tinggi harus dilatih keterampilan kritis, kreatif, pemecahan masalah, dan membuat keputusan. Selanjutnya, disampaikan oleh Ennis (1993) bahwa evaluasi terhadap kemampuan berpikir kritis antara lain bertujuan untuk mendiagnosis tingkat kemampuan siswa, memberi umpan balik keberanian berpikir siswa, dan memberi motivasi agar siswa mengembangkan kemampuan berpikir kritisnya. Selama ini guru cenderung menguatkan aspek verbal siswa dengan menghafal textbook yang dijadikan pegangan dalam pembelajaran.

Tinjauan terhadap kenyataan pada mata kuliah Anatomi Tumbuhan Pendidikan Biologi FKIP UM Metro menunjukkan bahwa pendidikan belum mencapai keberhasilan yang memadai dilihat dari proses maupun hasil belajar. Pembelajaran belum memperhatikan aktivitas belajar yang menunjukkan pengembangan karakter. Metode ceramah masih mendominasi proses pembelajaran, pola pembelajaran teacher centered masih sangat kuat, dosen banyak yang belum mengembangkan dan memberdayakan kemampuan berpikir kritis dalam pembelajaran, siswa hanya menghafal konsep-konsep dari textbook yang diberikan oleh guru.

Berdasarkan kenyataan pendidikan nasional dan khususnya pendidikan tinggi khususnya di FKIP UM Metro tersebut, maka diperlukan studi yang mengkaji strategi pembelajaran dan kemampuan akademik sebagai bagian dari komponen pendidikan. Salah satu strategi pembelajaran yang memberdayakan kemampuan berpikir kritis, berorientasi konstruktivistik dan learning community 
adalah cooperative learning (Slavin 1995; Arends, 2004). Disampaikan oleh Slavin (1995) bahwa dengan cooperative learning siswa melakukan belajar bersama menuntaskan materi dan saling berbagi pemikiran. Ditambahkan oleh Johnson dan Johnson (1997) dan Ibrahim et al (2000) bahwa dengan cooperative learning akan melatih kebersamaan siswa dalam keberagaman dan keterampilan sosial. Ditambahkan oleh Lord (2001) bahawa dengan cooperative learning akan meningkatkan kemampuan berpikir sains biologi siswa, sikap, evaluasi, keterampilan sosial, dan keterampilan praktis. Corebima (2007a; 2007b) menyatakan bahwa strategi cooperative learning sangat berpotensi memberdayakan pamahaman konsep dan kemampuan berpikir siswa berkemampuan akademik rendah dibanding yang tinggi.

Strategi cooperative learning memiliki bermacam-macam tipe, di antaranya Think Pair Share (TPS). Strategi TPS dalam sintaksnya memberikan kesempatan kepada siswa untuk berpikir mendalam (think) tentang pertanyaan-pertanyaan yang diajukan oleh guru, selanjutnya siswa mendiskusikan dalam kelompok atau pasangannya (pair) dan menjelaskan kepada siswa secara keseluruhan (share) (Slavin, 1995; Arends, 2004). Strategi TPS memungkinkan siswa memanfaatkan sebaik-baiknya waktu tunggu untuk mempertajam logika berpikir dari permasalahan atau pertanyaan yang diberikan guru (Allen dan Tanner, 2002). Penelitian-penelitian sebelumnya menunjukkan bahwa strategi TPS membantu siswa meningkatkan prestasi belajar, kemampuan berpikir kritis, minat, dan kerjasama anggota dalam kelompok (Rustini, 2005; Iqbal, 2005; Jannah, 2006; Yuanita, 2007; dan Safitri, 2008;). Dibandingkan dengan pembelajaran konvensional dan Numbered Head Together (NHT), strategi TPS memberikan pengaruh lebih baik (Rustini, 2005; dan Rozi, 2007).
Sintaks TPS memiliki penekanan pada kemampuan berpikir individu, berdiskusi dengan pasangan, kemudian hasil diskusi di-sharing-kan kepada anggota kelasnya. Implementasi TPS memiliki sinergisitas tinggi untuk meningkatkan kemampuan berpikir kritis siswa. Berdasarkan rasionalitas strategi TPS dari segi kelebihan dan sintaks tersebut, maka peneliti melakukan penelitian yang mengaplikasikan strategi TPS dengan modifikasi menjadi TPSS (Think Pair Square Share). Melalui strategi ini diharapkan karakter mahasiswa berkembang, seperti kemandirian, kerjasama, teliti, peduli, ulet, tekun, dan bertanggung jawab.

\section{METODE}

Jenis penelitian ini adalah Penelitian Tindakan Kelas yang dilaksanakan pada kegiatan Lesson Study. Kegiatan diawali dengan perencanaan (plan), bertujuan menghasilkan rancangan pembelajaran. Plan dilaksanakan secara kolaboratif beberapa dosen serumpun membahas Rencana Pelaksanaan Pembelajaran (RPP), Lembar Kegiatan Mahasiswa (LKM), dan prangkat pembelajaran lainnya. Selanjutnya kegiatan pelaksanaan (do), yaitu penerapan pembelajaran yang telah direncanakan. Dosen model menyelenggarakan pembelajaran, dosen lain berperan sebagai observer. Fokus observasi diarahkan pada mahasiswa belajar, bukan pada dosen yang sedang mengajar. Tahap akhir kegiatan adalah pengamatan dan refleksi (see), yaitu penyampaian hasil pengamatan oleh model sendiri dilanjutkan oleh observer. Kegiatan ini bertujuan menemukan kelebihan dan kekurangan pelaksanaan pembelajaran. Keseluruhan tahapan Lesson Study tersebut sesuai dengan siklus pada PTK, yaitu plan, acting, observing, dan reflection.

Penelitian ini dilaksanakan pada mata kuliah Anatomi Tumbuhan Program Studi Pendidikan Biologi semester ganjil 
Tahun Akademik 2010/2011, dari bulan Oktober sampai Desember 2010. Instrumen yang digunakan untuk mengukur kemampuan berpikir kritis dalam penelitian ini adalah: 1) tes kemampuan berpikir kritis, digunakan untuk memperoleh data kemampuan berpikir kritis. Tes diberikan sebelum siklus dan sesudah siklus. 2) lembar observasi, digunakan untuk mengamati aktivitas mahasiswa yang menunjukkan karakter positif dalam proses pembelajaran. Analisis deskriptif hasil observasi digunakan untuk mendeskripsikan kemampuan berpikir kritis, aktivitas belajar, dan pengembangan karakter mahasiswa dalam pembelajaran.

\section{HASIL}

Kemampuan berpikir kritis mahasiswa setelah mengerjakan tes kemampuan berpikir kritis termasuk kategori baik, meningkat 33\% dari sebelum implementasi strategi TPSS ke siklus I, sedangkan dari siklus I ke siklus II mengalami peningkatan 14\%. Peningkatan kemampuan berpikir kritis mahasiswa dimungkinkan terjadi karena implementasi strategi TPSS. Aktivitas belajar mahasiswa selama implementasi TPSS termasuk kategori baik, aktivitas ini meliputi bertanya, menjawab, mengerjakan tugas, dan menganggapi pendapat teman lainnya. Bila diamati, aktivitas mahasiswa meningkat 38\% dibandingkan hasil refleksi awal sebelum implentasi strategi TPSS. Peningkatan dari siklus I ke siklus 2 sebesar 12\%. Pengamatan terhadap karakter kemandirian, kerjasama, ketelitian, peduli, ulet, tekun, dan bertanggung jawab menunjukkan peningkatan $43 \%$ dari sebelum pelaksanaan pembelajaran menggunakan strategi TPSS ke siklus I.

Mahasiswa bekerja dan berpikir mandiri menunjukkan sikap kemandirian, berpasangan menunjukkan sikap keterbukaan, mau menerima pendapat orang lain, bertanggung jawab terhadap hasil kerjannya, dan kemauan bekerja sama. Demikian juga ketika berempat dalam kelompok menunjukkan kemauan bekerja sama, sesuai filosofi budaya Indonesia yaitu bergotong royong.

Hasil penelitian ini menunjukkan bahwa pembelajaran dengan strategi TPSS memberikan kontribusi yang positif pada kemampuan berpikir kritis, dan pembentukan karakter mahasiswa yang ditunjukkan dengan aktivitas belajar selama pembelajaran berlangsung.

\section{PEMBAHASAN}

Siswa yang mengikuti pembelajaran dengan strategi TPSS mengalami peningkatan rata-rata skor kemampuan berpikir kritis, baik sebelum siklus I, setelah siklus I, dan setelah siklus II. Pembelajaran yang dilaksanakan dengan strategi TPSS menekankan penyampaian materi yang dilakukan dengan think, pair, square, share. Anggota kelompok bekerja sama menggunakan lembar kegiatan atau perangkat pembelajaran yang lain untuk menuntaskan materi pembelajaran dan kemudian saling membantu satu sama lain untuk memahami materi pembelajaran melalui tutorial, kuis atau melakukan diskusi. Kerja kelompok dilaksanakan dengan menekankan tahap thinking, pairing, dan sharing. Kerja sama yang baik dalam kelompok ditunjukkan dengan pembimbingan dari siswa yang memiliki kemampuan akademik tinggi kepada siswa yang memiliki kemampuan akademik rendah, baik pada pairing maupun pada sharing sehingga terjadi proses scaffolding. Pembelajaran ini memiliki beberapa perspektif yang dapat dikembangkan, yaitu perspektif motivasi, sosial, kognitif, elaborasi kognitif, dan psikologis (Slavin, 1995; Arends, 2004). Proses pembelajaran dengan strategi TPSS ini juga sesuai dengan paradigma pembelajaran konstruktivistik yang menekankan pengembangan kemampuan siswa dalam menemukan jawaban atas permasalahan yang sedang dikaji (Nur, 2000). Selain itu melatih mahasiswa 
untuk mengembangkan sikap sebagai embrio pembentukan karakter.

Apabila dikaitkan dengan hasil penelitian sebelumnya, hasil penelitian ini mendukung penelitian tentang implementasi strategi TPS, yaitu penelitian yang dilakukan oleh Rustini (2005), dan Iqbal (2005), bahwa pembelajaran dengan strategi TPS dapat meningkatkan kemampuan berpikir kritis siswa. Pada implementasi strategi TPS siswa dalam kelas dibentuk menjadi kelompok belajar dengan anggota 2 orang, setiap kelompok memiliki anggota yang heterogen, terdiri dari laki-laki dan perempuan, berasal dari berbagai suku, memiliki kemampuan tinggi, sedang, dan rendah (Slavin, 1995; Ibrahim et al, 2000). Seluruh anggota kelompok ini bersatupadu untuk sebuah pembelajaran yang efektif. Kerja kelompok yang dilaksanakan dalam tahapan TPS, yaitu thinking, pairing dan sharing menjadikan wahana bagi siswa untuk mengembangkan kemampuan berpir kiritis. Proses scaffolding dalam penelitian ini, yaitu pada tahap thinking, pairing, dan sharing memungkinkan siswa yang berkemampuan atas membantu siswa berkemampuan bawah, sehingga siswa berkemampuan bawah mengalami peningkatan kemampuan berpikir kritis.

Refleksi mengenai kekurangan dalam penelitian ini adalah belum adanya lembar observasi yang dapat mengamati peningkatan kemampuan berpikir kritis siswa dalam pembelajaran, selain tes yang sudah dilaksanakan seperti untuk mengetahui ranah kognitif. Demikian juga untuk mengamati pembentukan karakter dengan tes, sangat sulit dilakukan, tetapi dapat disampaikan sebagai motivasi pengembangan karakter peserta didik. Menurut peneliti, untuk kepentingan mengungkap perubahan-perubahan kemampuan berpikir kritis dan pembentukan karakter selama proses pembelajaran sangat diperlukan, sehingga untuk penelitian-penelitian selanjutnya sebaiknya peneliti mengembangkan instrumen observasi kemampuan berpikir kritis siswa selama proses pembelajaran.

\section{KESIMPULAN DAN SARAN Kesimpulan}

Berdasarkan hasil penelitian dan pembahasan, dapat disimpulkan bahwa strategi TPSS meningkatkan kemampuan berpikir kritis dan dapat dijadikan wahana pengembangan karakter mahasiswa.

\section{Saran}

Peneliti menyarankan kepada pendidik untuk mengimplentasikan strategi pembelajaran TPSS untuk meningkatkan kemampuan berpikir kritis dan pengembangan karakter.

\section{UCAPAN TERIMA KASIH}

Penelitian ini dilaksanakan dalam Program Perluasan Lesson Study di Perguruan Tinggi, oleh karena itu, peneliti mengucapkan terima kasih kepada Ditjen Dikti Depdiknas yang telah membantu terlaksananya penelitian ini.

\section{DAFTAR RUJUKAN}

Allen, D. and Tanner, K. 2002. Approaches in Cell Biology Teaching. Journal The American Society for Cell Biology. 1(3-5) 3-5.

Arends, R.I. 2004. Learning to Teach. Sixth Edition. New York: Mcgraw Hill.

Corebima, A.D. 2006. Keterampilan Proses: Pemberdayaan dan Asesmen. Makalah disajikan dalam Workshop bagi Mahasiswa dan Guru Pelaksana PTK A2 di Batu, Malang, 24 Juni 2006.

Corebima, A.D. 2007a. Learning Strategies Having Bigger Potency To Empower Thinking Skill and 
Concept Gaining of Lower Academic Students. Proceedings of Redesigning Pedagogy Conference, Nanyang, May 28-30 2007.

Corebima, A.D. 2007b. Learning Strategies To Empower Students Thinking Skill. Proceeding of International Conference on Science and Mathematics Education (CosMed) SEAMEO RECSAM, Malaysia, Nopember 13-16 2007.

Costa, A.L. dan Presseisen, B. Z. 1985. Glossary of thinking skills. Dalam A.L. Costa (Ed.). Developing Minds: A Resource Book for Teaching Thinking. (hlm. 303-312). Alexandria : ASCD.

Depdiknas. 2003. Sistem Pendidikan Nasional. Undang-undang Nomor 20 Tahun 2003. Jakarta: Depdiknas.

Depdiknas. 2005. Standar Nasional Pendidikan. Peraturan Pemerintah Republik Indonesia Nomor 19 Tahun 2005. Jakarta: Depdiknas.

Ennis, R.H. 1993. Critical Thinking Assesment. Journal Theory and Practice. $\quad 32(3) \quad$ Summer 1993. Ohio: Ohio State University.

Fogarty, R. and McTighe, J. 1993. Critical Thinking Assesment. Journal Theory and Practice, 32(3) Summer 1993. Ohio: Ohio State University.

Friedrichsen, P.M. 2001. A Biology Course for Prospective Elementary Teachers. Journal The American Biology Teacher, 63(8): 562-568.

Ibrahim, M., Rachmadiarti, F., Nur, M., Ismono. 2000. Pembelajaran Kooperatif. Surabaya: UNESAUniversity Press.

Ibrahim, M. dan Nur, M. 2000. Pengajaran Berdasar Masalah. Surabaya: UNESA-University Press.
Iqbal, M. 2005. Pengaruh Pembelajaran Kooperatif Teknik Think-Pair-Share terhadap Kemampuan Kognitif Siswa Kelas 1 SMP Pada Konsep Ekosistem, (Online), (http://digilib.upi.edu/pasca/availabl e/etd-1205105-085615/, diakses 22 Pebruari 2008).

Jannah, I. N. 2006. Pengaruh Penerapan Pola PBMP (Pemberdayaan Berpikir Melalui Pertanyaan) dengan Metode Think Pair Share Terhadap Kemampuan Berpikir dan Hasil Belajar Siswa Berkemampuan Tinggi dan Rendah pada Pembelajaran IPA Biologi Kelas VII1 SMPN 1 Tumpang Kabupaten Malang. Skripsi tidak diterbitkan. Malang: Universitas Negeri Malang.

Johnson, R and Johnson, D. 1997. Cooperative Learning and Conflict Resolution. Minneapolis: University of Minnesota, (Online), (http://www. newhorizons. org, diakses 6 Nopember 2007).

King, A. 1994. Inquiry as a Tool in Critical Thinking. Dalam. D. Halpern and Associates (Eds.), Changing College Classrooms: New Teaching and Learning Strategies for an Increasingly Complex World. Jossy-Bass Publishers.

Krulik, S. and Rudnick, J.A. 1999. Innovative Task to improve Critical and Creative Thinking Skills. Dalam I. Stiff (Ed.). Developing Mathematics Reasoning in Grade K-12. Reston: National Council of Teachers of Mathematics.

Liliasari. 2000. Model Pembelajaran untuk Meningkatkan Keterampilan Berpikir Konseptual Tingkat Tinggi Calon Guru IPA. Prosiding Seminar Nasional, Malang, 23 Pebruari 2000. Malang: Ditjen Dikti 
Depdiknas-JICA-IMSTEP. Hlm 135-140.

Lord, T.R. 2001. Reasons for Using Cooperative Learning in Biology Teaching. The American Biology Teacher, 63(1), 30-36.

McMurarry, M.A. Beisenherz and Thompson, B. 1991. Reliability and Concurrent Validity of A Measure of Critical Thinking Skills in Biology. Journal of Research in Science Teacher, 28(2): 183-192.

Muhfahroyin. 2009a. Memberdayakan Kemampuan Berpikir Kritis Siswa melalui Pembelajaran Konstruktivistik. Jurnal Pendidikan dan Pembelajaran. Volume 16 (1): 8893.

Muhfahroyin. 2009b. Pengaruh Strategi Think Pair Share (TPS) dan Kemampuan Akademik terhadap Kemampuan Berpikir Kritis Siswa SMA di Kota Metro. Jurnal Pendidikan dan Pembelajaran. Volume 16 (2): 107-115.

Nur, M. 2000. Pengajaran Berpusat kepada Siswa dan Pendekatan Konstruktivis dalam Pengajaran. Surabaya: UNESA-University Press.

Rustini, I, 2005. Keterampilan Berpikir Kritis Siswa Melalui Pembelajaran Kooperatif Teknik Think-PairSquare Dalam Kegiatan Praktikum Materi Pencemaran Air (Studi
Kasus SMA 2 Bandung Kelas X), (Online), (http:// digilib.upi. edu/pasca/ available/ etd- 0202106091451/, diakses 6 Nopember 2007).

Safitri, D.A.A. 2008. Penerapan model Pembelajaran Kooperatif Model TPS untuk Meningkatkan Kemampuan Berpikir dan Prestasi Belajar Siswa Kelas XI IPS II SMAN 1 Boyolangu Tulungagung. Skripsi tidak diterbitkan. Malang: Universitas Negeri Malang.

Sidi, I. J. 2001. Menuju Masyarakat Belajar. Jakarta: Paramadina.

Slavin, R.E. 1995. Cooperative Learning; Theory, Research, and Practice. Massachusetts: Allyn and Bacon.

Splitter, L.J. (1992). Critical Thinking: What, Why, When, and How. Australia: Australian Council for Education Research.

Winkel, W.S. 2004. Psikologi Pengajaran. Jakarta: Gramedia Widiasarana Indonesia.

Yuanita, A.R. 2006. Hubungan Antara Kemampuan Berpikir dan Hasil Belajar pada Pembelajaran Biologi dengan Pola Pemberdayaan Berpikir Melalui Pertanyaan (PBMP) dan Think Pair Share (TPS) di SMPN 18 Malang. Skripsi tidak diterbitkan. Malang: Universitas Negeri Malang. 